\title{
Standardization in digital manufacturing: implications for Russia and the EAEU
}

\author{
Yulia V. Turovets
}

E-mail: yturovecz@hse.ru

\section{Konstantin 0. Vishnevskiy}

E-mail: kvishnevsky@hse.ru

National Research University Higher School of Economics

Address: 11, Myasnitskaya Street, Moscow 101000, Russia

\begin{abstract}
The shift to digital technologies in various industries is one of the key goals in the digital agenda. Due to the essential role of interoperability of products and elements in complex systems, standardization stays in the forefront of government policy and business. In manufacturing systems, standards are of a prime importance, since they serve as a channel for modernization and innovation speedup. This paper makes a contribution to the currently rare literature on digital manufacturing standardization as a policy tool to promote digital technologies in business. By comparing five national cases of China, Germany, Japan, the Republic of Korea and the USA, we introduce national models of standardization in smart manufacturing according to the extent of state participation in standardization. In doing so, we examined initiatives in industry, digitalization, the development of a national system of standards, the reference architecture of digital production, as well as the countries' cooperation in the field. Along with this, an overview of international initiatives in the field is presented, namely the ISO and the IEC. Taking into account the existing landscape, an assessment of the Russian case of digitalization in manufacturing and standardization is presented. Like China, Russia follows the third model of standardization. Given the results, we developed recommendations for Russia with the aim of intensifying efforts at standardization and the country's presence in the international agenda, as well as to develop a Russian framework for digital transformation in sectors and achieve related economic effects.
\end{abstract}




\section{Graphical abstract}

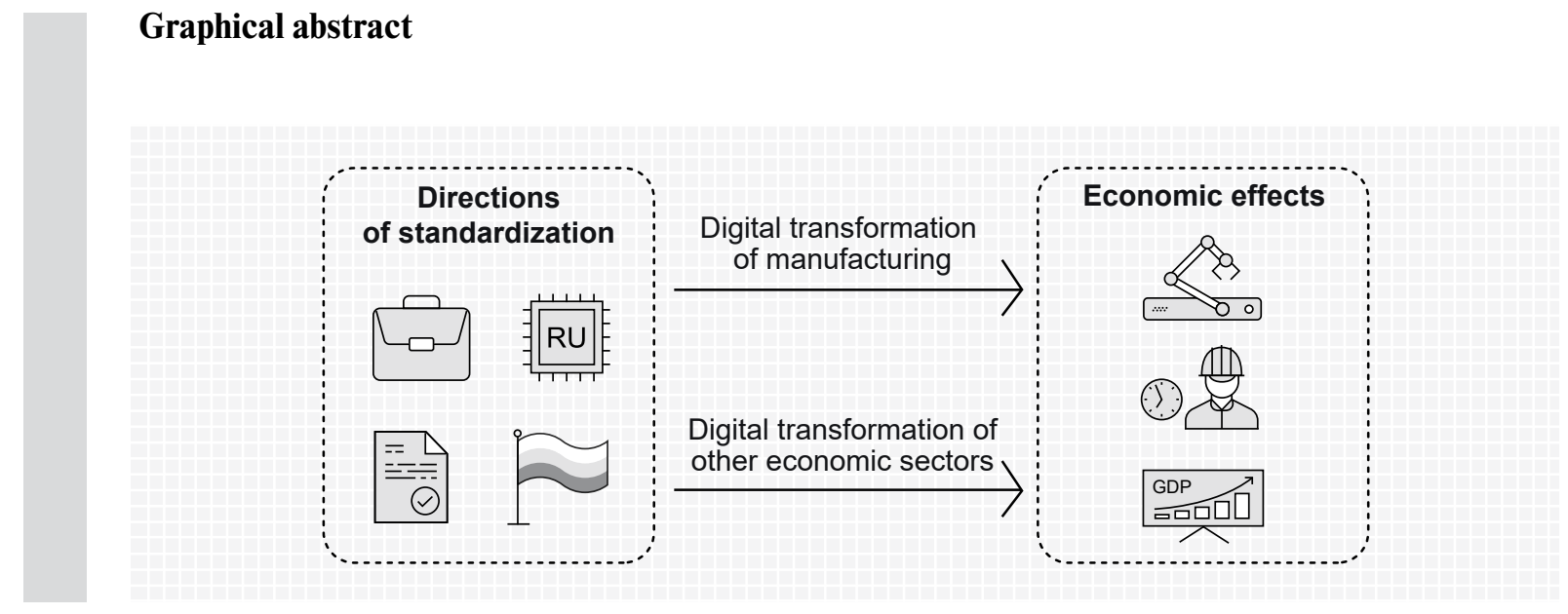

Key words: digital economy; digital manufacturing; standardization; technical committee; international standardization bodies.

Citation: Turovets Yu.V., Vishnevskiy K.O (2019) Standardization in digital manufacturing: implications for Russia and the EAEU. Business Informatics, vol. 13, no 3, pp. 78-96.

DOI: $10.17323 / 1998-0663.2019 .3 .78 .96$

\section{Introduction}

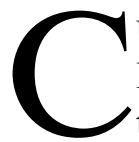

urrently digitalization is becoming a key issue in the industrial and innovation policy perspective and generates significant changes. A comprehensive intellectualization through information and communication technologies (ICT) leads to drastic rearrangement in production and businessprocesses facilitating cooperation in a global market $[1,2]$. The absence of standards is often seen as a barrier to digitalization.

Digitalization and its implications for upgrading the technological sector has several dimensions. On the one hand, some digital technologies could bring new concepts of business process management without significant change in the set of technologies. Nevertheless, automated systems and management systems should be integrated with existing equipment [3]. On the other hand, a complex digital transformation entirely restructures a company's technology architecture [4, 5].
Digitalization as a scientific field is in its infancy. There are several notions of digital manufacturing in existing literature, which include smart manufacturing, cyber-physical systems, Industry 4.0, the smart/digital factory and some others. It is a complex system that integrates the pull of production and information technologies that help to optimize on the production floor and drive product development in a virtual environment. In a more broad sense, it is a concept of how to exploit an extensive set of data in a most effective way. Cyber-physical systems (CPS), cloud computing, and the Internet of Things (IoT), big data, digital modeling, additive manufacturing, virtual reality constitute its technological core [6, 7]. Despite the common set of technologies, their application and business models in sectors differ significantly and affect innovative activity of enterprises [8].

In this respect, we suggest that standards serve as a mechanism to boost innovation and adop- 
tion of digital technologies in manufacturing industries. Based on a comparative analysis of national initiatives in China, Germany, Japan, the Republic of Korea, the United States in the field, we distinguished three main models describing digital manufacturing standardization in countries. We relied on several parameters for the country analysis, including the national standardization system, industrial and digitalization related strategies, projects in digital manufacturing and standardization, elaboration of reference architecture and international cooperation in the field. This study also gives an overview of the international standardization landscape with respect to the Russian position in it. In order to present recommendations for Russia, we analyzed the Russian and foreign digital agenda and the role of standardization.

\section{Digital manufacturing from the standardization perspective}

Digitalization becomes indispensable for technological upgrading in different sectors [8]. There is a growing interest in smart manufacturing from government, business and academia. This is evidenced by national digitalization programs, corporate transformation strategies, as well as by a growing number of scientific publications. The available literature combines several approaches to the study of digital production, including technological trends [9-11], design principles [6, 12], the effects of its adoption [7, 13]. Other papers address mainly technological issues introduced by the integration of information technologies in production systems $[14,15]$. However, the number of studies focused on innovation outcomes of digital manufacturing standardization is still limited.

As the innovation cycle accelerates, standards and related activities become a tool to solve global challenges, especially in the hightech sectors of industrial production $[16,17]$.
The process of standards development is a consensus-based, open and transparent one that facilitates the agreement of stakeholders on technical specifications and implementation $[18,19]$. Moreover, standards promote innovation spread by harmonization of technological solutions in complex systems, with replicability and conformity assessment (security, compatibility, etc.) [20].

Thus, standards facilitate knowledge transfer, its dissemination and promote further innovation [18, 21]. Massive use of information technologies requires compatibility of systems, products and services in the global market, the key tool for which are the standards [22, 23]. From the evaluation perspective, standards could serve as an indicator of project effectiveness, including projects supported by the state. Therefore, standards can stimulate development of new technological solutions and improvement of existing ones [20].

Standards in the field of digital technologies have particular characteristics in comparison with other domains. Firstly, digital technologies constitute complex systems comprising a range of parts and elements, both hardware and software, which can be developed by different suppliers in different ways, though interoperability must be ensured [22]. Secondly, modern information systems are designed with high switching costs. For the customer, its implementation means significant expenses for integration, learning, etc. Thirdly, intrinsic network effects are achievable only in case the number of users is growing [23].

Most studies referring to the ICT industry analyze standards elaborated predominantly within industrial consortia. By comparison, industrial and more precisely the machinebuilding sector receives not enough attention. Machine-building industries generate high added value, and companies of the sector are actively participating in official standardization organizations [24]. 
In the literature, two classes are distinguished - de facto and de jure standards. De jure or formal standards are developed by standard-setting organizations (SSO) or standard developing organizations (SDO) [24]. De facto standards arise as a result of market competition between several specifications and are introduced mostly by private companies [17]. Due to technology convergence, consortia and alliances become important modes of cooperation in standardization and submit their standards to formal organizations [19, 25].

The role of government in the field of standardization is mainly focused on coordination of standards development and mitigating risks for participants. Public entities contribute to creation of partnerships and alliances at the national level, often being an initiator [20]. Modernization of industries in turn leads to improvement of standardization itself; in particular, it fosters the shift of services standardization to the digital environment and the elaboration of digital standards.

In this paper, standardization is considered to be an efficient government mechanism of digitalization in industries and brings new evidence to the strand of literature dedi- cated to innovation policy in digital era. Based on national cases of smart manufacturing and comparison with Russia, a set of recommendations for Russia was developed.

\section{International landscape in the field of digital manufacturing and standardization}

\subsection{National policy for digitalization}

To select countries for the analysis, we used the WEF Readiness for the Future of Production index. It comprises several dimensions structure and drivers of production; each of them includes a number of sub-indicators. For our purposes, we assessed countries by two parameters - scale (refers to the production structure parameter) and technology and innovation (refers to the drivers of production). The first one sheds light on the general volume of production and, thus, on the scope of standards application by manufacturing companies, since standards fulfill an economic function only in case of wide recognition. The second reflects the level of technological development in countries and, respectively, allows us to anticipate which countries are likely to be leaders in the field (Table 1) [26].

Scores of the selected countries according to the WEF Readiness for the Future of Production

\begin{tabular}{c|c|c}
$\begin{array}{c}\text { Countries } \\
\text { in the ranking }\end{array}$ & $\begin{array}{c}\text { Structure } \\
\text { of production - Scale }\end{array}$ & $\begin{array}{c}\text { Drivers } \\
\text { of Production -Technology \& Innovation }\end{array}$ \\
\hline USA & 10 & 8 \\
\hline Germany & 4 & 16 \\
\hline Japan & 5 & 17 \\
\hline Republic of Korea & 2 & 25 \\
\hline China & 1 & 25 \\
\hline
\end{tabular}

Source: [26]. 
Germany and the USA are on the intersection of these two facets and thus are leaders; China, the Republic of Korea and Japan occupy leading positions in terms of scale. Their strong positions in the field of digital production are supported by the existence of national industrial strategies and a standardization approach.

On the national level, the following parameters were analyzed: the national system of standards development, initiatives in industry, digitalization and standardization, reference architecture of digital production, cooperation among countries. Based on this, we distinguished three main models in the manufacturing standardization landscape: marketcentered (the USA, the Republic of Korea), a balanced approach based on a private-public partnership (Germany, Japan) and a government-centered approach (China). The results of the analysis are given below.

\section{National system of standardization}

In the USA, standardization is driven mostly by business players, whereas state bodies, including various agencies and institutes, perform a coordinating role by providing the general regulatory framework, related research and expertise [27].

The second model, public-private partnerships, involves greater participation of government, industry associations and major research organizations. This model is attributed to Germany, the Republic of Korea and Japan [28]. It is important to mention that the German approach is characterized by a large focus on technological aspects [29]. With Japan's high involvement in global value chains, the country is under-represented in transnational consortia and alliances led by the U.S. firms. Nevertheless, there are several collaborations of Japanese firms with European, Asian and American partners [30].
The Chinese model is based on mostly state activities: the government raises funds and coordinates various projects within the framework of the "Chinese Standards 2035" strategy. Its main focus is to intensify research and development. Development of their own standards in China is driven by both external factors and internal purposes related to industrial upgrading. China is actively involved in international standards activities, especially in the field of $5 \mathrm{G}$ technologies [31].

\section{Initiatives in the field of digital manufacturing and standardization}

Standardization is considered to be an important policy tool to tackle economic challenges. The German case reveals that along with research activities and information infrastructure standards ensure competitive advantages for the country, where German business traditionally plays the main role [32]. Overall, digitalization in manufacturing helps to keep Germany high-value manufacturing export, ensures competitiveness in the global value chains for Korea [33]. GVC domination is also the main concern for the U.S., since manufacturing plays a key role for international competitiveness and is supported by the leading position in R\&D. China's efforts focus mainly on structural change, since information technologies in manufacturing should favor innovation enhancement of national economy and its technological upgrading [34].

Digital agendas of most leading countries, in addition to the strategies themselves, encompass separate initiatives for industry standardization as well. Such initiatives have aimed at creation of standards and international promotion, i.e. its replication and building smart factories. Projects in standardization cover a wide range of activities, including testing of business models, elaboration of scenarios of technology adoption (e.g., the Labs Network 
Industrie 4.0 in Germany), assistance with operational issues related to introduction of digital technologies in manufacturing (Plattform Industrie 4.0 in Germany). Within the framework of such public-private partnerships, government provides strategic guidance and integrates participants into a single ecosystem [35].

Currently there are two dominant approaches in the manufacturing digitalization - German and American. The former focused more on production aspects (hardware) of digitization and integration of cyber-physical systems, while the latter considers digitalization of industry more broadly as part of the system of the industrial internet in sectors.

A market-centered model represents another pattern, where a large part of standards is developed in consortia and alliances, the most significant of which both in the U.S. and international level is the Industrial Internet Consortium (IIC) established in 2014 by leading corporations. The IIC developed the reference architecture for the Internet of Things in industry, healthcare, energy, transport and public services. Participation in the consortium allows companies to get access to test-beds and to get acquainted with the regulatory framework in the field of new technologies. Other international industry consortia and alliances provide a similar support [36].

Along with business initiatives, there are also other U.S. state programs related inter alia to standardization. Under the "Manufacturing USA" program, the Digital Manufacturing and Design Innovation Institute (DMDII) funded by the U.S. Department of Defense and coordinated by the National Institute of Standards and Technology was established. It is a place for collaboration in $\mathrm{R} \& \mathrm{D}$, commercialization and testing new solutions for different industries [36]. Institutes create effective and replicable solutions for enterprises by consolidating efforts of ministries, private companies, universities and research organizations [37].
Other countries are implementing similar projects. The Korea Manufacturing Innovation 3.0 is part of the comprehensive Korean Creative Economy (CEI) strategy. With respect to specialization of regions, 17 innovation centers that cover a range of digital technologies across the country were created. These centers are managed by large Korean corporations like Samsung, Hyundai, etc. ("Smart machinery" led by Doosan, "Shipbuilding/ machinery", "Textile/electronics" by Hyundai Heavy Industries, "Smart Factory" by Samsung, automobile by Hyundai and Kia Motors) [37, 38].

Japan has both business-led (IoT Acceleration Consortium) and state-led (Industrial Value Chains Initiative - IVI, "Connected Industries", the Robot Revolution Initiative of Japan - RRI) initiatives in smart manufacturing, which are in general coordinated by government. The Industrial Value Chain Initiative (IVI) was introduced in 2015 as a cooperation platform of national manufacturing firms coordinated by the Ministry of the Economy, Trade and Industry (METI). It accumulates joint use cases and scenarios in smart manufacturing thus helping to implement flexible standards and models in different sectors. There is a strong cooperation across working groups on standardization of the initiatives [39]. The government makes a particular effort to promote standards for robotic systems across different sectors within the country and globally, since robotics is one of the five priority areas for the national economy in the long-run, according to the Robot Revolution Initiative of Japan (RRI) [40].

China follows the third approach, which is characterized by the development of its own model of digitalization based on the combination of the best world practices with a leading government role. The main task is not only modernization, but also radical structural transformation of industry, with an increase of value added and reorientation towards 
high-tech products [36]. Active state support is based on bilateral cooperation with leaders (Germany and the United States), while the "Standards of China 2035" strategy is aimed at creating Chinese standards by intensifying efforts in the field of research and development [41].

Despite the similarity of national goals for standardization, the countries' differences in economic and technological competences require more adaptive mechanisms in standardization. Public-private partnerships are the most appropriate way to realize digital projects.

\section{Reference architecture of digital manufacturing}

Reference architectures are more conventional to information and communication technologies. From smart manufacturing perspective, the term means "a model for a class of architectures," i.e. a pool of rules and principles to describe physical systems in a digital world [42].

Leading countries are striving to develop their own reference models. The Reference architecture model Industrie 4.0 (RAMI 4.0), introduced by the Plattform Industrie 4.0 and the Industrial Internet Reference Architecture (IIRA) by the IIC are main approaches. Japan has the harmonized with the RAMI principles the Industrial Value Chain Reference Architecture (IVRA) [43]. Korea is also undertaking efforts to elaborate own reference model with a particular attention to SME digitalization (Smart Factory Reference Model) [44].

China is also developing its own model the China Intelligent Manufacturing System Architecture (IMSA). In the framework SinoGermany bilateral cooperation the IMSA and the RAMI are harmonized, which is determines Chinese orientation on the German approach [45].

\section{Cooperation \\ in the field of digital \\ manufacturing}

In order to promote national approaches to digitalization of production, the leading countries are building networks with economic and trade partners in a bilateral way.

More precisely, Germany collaborates with China (a joint Sino-German Commission on Standardization cooperation); Japan in the framework of the Plattform I4.0 and Japanese Robot Revolution Initiative, with Korea within the Smart Factory Web, which is a joint Korean-Germany initiative supported by government and some others [45-48]. In addition at the national level, Germany (Plattform Industrie 4.0) with France (Alliance Industrie du Futur) and Italy (Piano Industria 4.0) have established a trilateral initiative and a working group based on the German reference architecture (The Paris Declaration for Smart Manufacturing) [49].

The IIC network of partners is also large and comprises cooperation between the Japanese IVI and the IIC (the Liaison Working Group) [50], the Korean Smart Factory Web (a testbed of the Industrial Internet Consortium) and some others [48]. Moreover, alignment between the RAMI and the IIRA shapes the digital agenda in industry and helps to secure global interoperability [51].

A summary analysis of the countries is shown in Figure 1.

Standardization receives greater attention from national governments and international organizations, occupying an important place in bilateral and multilateral relations. Currently, standards development in production industries is led by Germany and the USA, with reference architectures and cross-country cooperation. The major part relies on wide public-private partnerships. 
Model 1

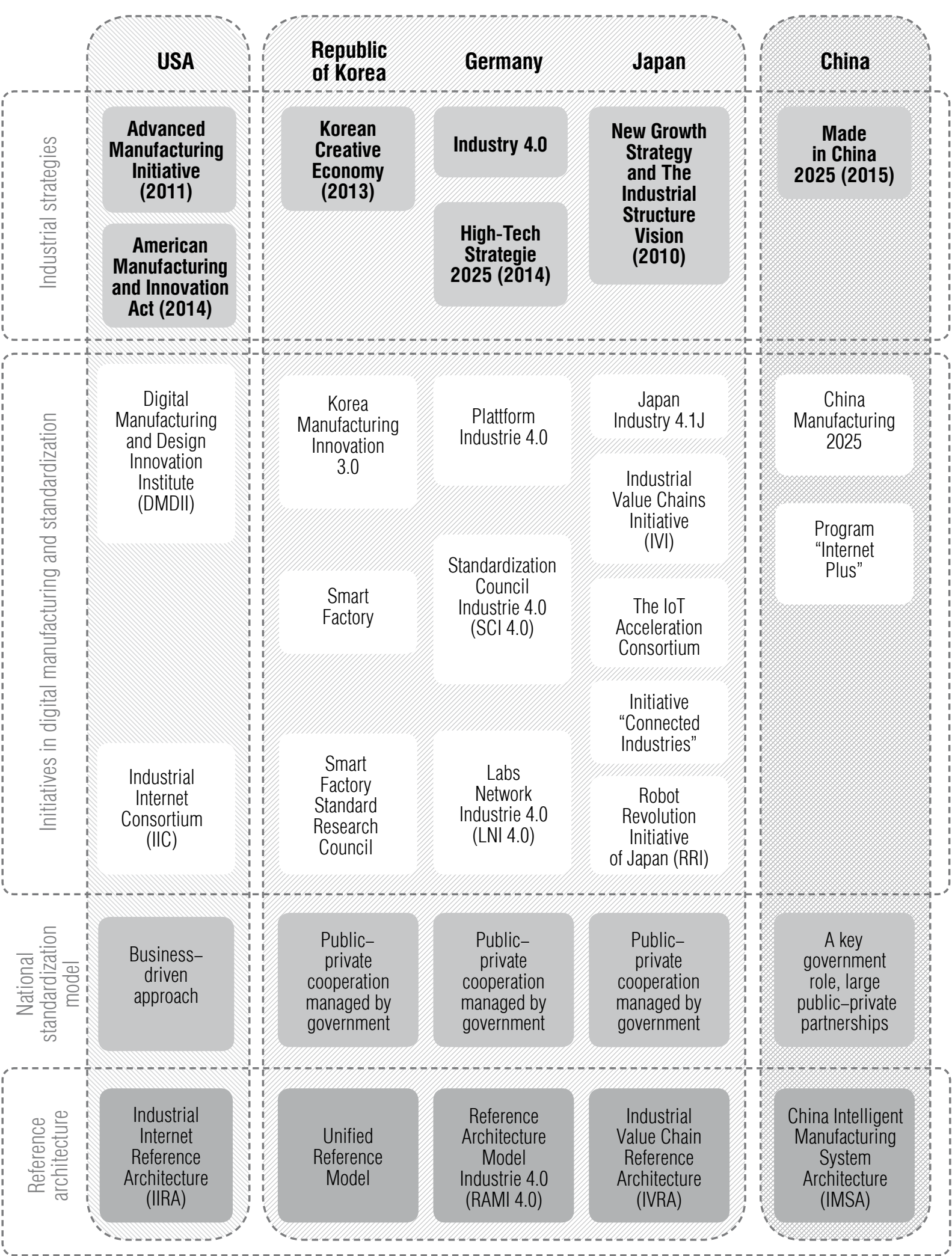

Fig. 1. Standardization digital manufacturing landscape in selected countries 


\subsection{International bodies involved with standardization in digital manufacturing}

International organizations in standardization, primarily the ISO and IEC, pay significant attention to digital production and related issues. Some initiatives are performed via joint technical committees (JTC) (Figure 2).

Technical Committees (TC) are working on functional compatibility of systems and cybersecurity, as well as the extension and systematization of existing approaches by proposed participants. In this regard, within the ISO and IEC two strategic bodies have been established - ISO/SMC and IEC/SC, which bring together representatives of all technical committees related to production and information technologies [35]. In addition to joint initiatives of the ISO and IEC, there are several technical committees focused on smart production - the ISO TC 184 (product data, compatibility, integration, architecture for industrial automation, and TC 65 IEC (control of industrial processes and their automation and integration of product data and processes).

Along with international official organizations in the field of digital production, there are a number of industrial consortia and alliances that are becoming important participants in developing standards. Among them are the MTConnect, OPC Foundation and MESA. Standards developed by alliances may be submitted to the official international organizations for standardization. Some of them provide free access to their standards and technical information; for example, the OPC Foundation conducts its own certification and testing [29]. With a significant number of players in the international scope, standards and norms alignment remains a key point [51].

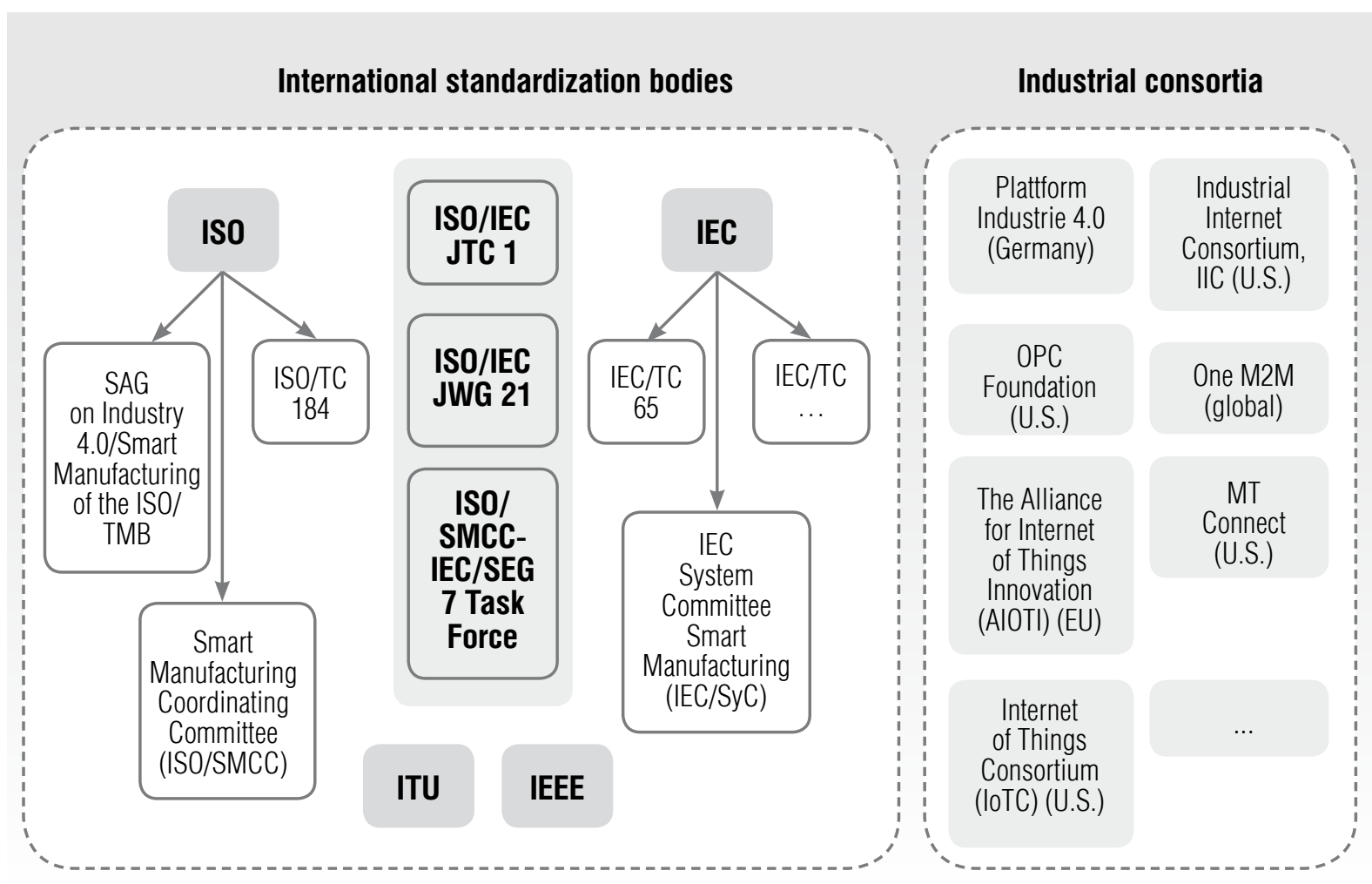

Fig. 2. International landscape of digital manufacturing 


\section{Russian perspectives in standardization of digital manufacturing}

\subsection{Factors and conditions of digitalization in Russia}

The digital agenda in Russia is associated with significant socio-economic effects. By 2030 digitalization may become the key driver of economic growth: from 2017 to 2030 the contribution of sectoral digital transformation may account for as much as a $30 \%$ increase in GDP. The most significant effects related to digital technologies may be observed in the machinebuilding and chemical industries, where production efficiency will be about $5 \%$ due to the total factor productivity and the contribution of capital to value added [52].

The overall level of digital technologies use age varies widely across industries and enterprises. In recent years, large companies have introduced specialized software for functional fields, including management of finance operations, customer interaction, etc. Russian business considers digital technologies to be a source of strengthening market positions and gaining new opportunities in the long term [53]. However, the degree to which digital solutions are adopted in business remains low. From the sectoral perspective, manufacturing industry demonstrates a higher level of digitalization. Manufacturing firms rank first in electronic data interchange $(72.3 \%)$, but they lag far behind the ICT sector in terms of cloud services use (23.2\% versus $34.7 \%)$. In almost half of manufacturing enterprises $(46 \%)$, the level of digitalization is considered to be low [54].

Large-scale digitalization in industry is constrained by the lack of domestic equipment and specialized software. Russian industrial companies are not actively investing in domestic digital solutions and purchase predominantly foreign products and services. For example, the share of foreign robots, as well as smart control systems, is almost $100 \%$, CNC systems $-65 \%$
[55]. Imported industrial software, including PLM, CAD, CAM, CAE, accounted for $88 \%$ in 2014 [56]. As part of the sectoral plans for import substitution, the share of foreign products should be reduced by 2020 (industrial robots to $69 \%, \mathrm{CNC}$ systems - $20 \%$, engineering software $-60 \%)[55,56]$.

Nevertheless, Russia has the opportunities and resources for a transition to a digital economy. This includes a highly dynamic information technology market, the existence of public research and engineering centers, development of private research organizations, availability of scientific schools, and a high level information and communication infrastructure. The greatest demand is expected in sectors with complex products and high modeling needs (aerospace, automotive, shipbuilding); with large production capacities (production of equipment and general purpose machinery, electrical equipment), as well as transport engineering [57].

\subsection{Government policy in the digital economy on the national and supranational levels}

In Russia, goals related to digitalization are assigned a strategic priority and are set down in the Decree of the President of the Russian Federation No. 204 of 07.05.2018 "On national goals and strategic objectives for the development of the Russian Federation for the period up to 2024."

The main initiative is the program entitled "The digital economy of the Russian Federation" adopted in 2017 and transformed into a national project in 2018. The program includes six Federal Projects in the areas of regulations governing the digital environment, information infrastructure, information security, personnel for the digital economy, digital technologies and digital public administration. The activities of the national program are aimed inter alia at promoting the creation and imple- 
mentation of digital technologies in the economic and social sectors. At the same time, the main measures for standardization are set down in the Federal project "Normative regulation of the digital environment" [58].

Along with the federal programs, a number of ministerial projects are being developed, including on the digital industry managed by the Ministry of Industry and Trade. It also includes incentives for standardization and use of digital technologies [59].

A set of measures for industrial modernization is also included in the National Technological Initiative (NTI) in the area of "TechNet" and includes improvement of activities in the field of standardization and certification, the development of new approaches to standardization and the introduction of "factories of the future" standards [57].

The digital agenda including industry is one of the key measures to boost economic growth in the Eurasian Economic Union (EAEU). In accordance with the decision of the Supreme Eurasian Economic Council of October 11, 2017 No 12 "On the main directions of the digital policy of the EAEU until 2025," sectoral and cross-sectoral digital transformation are the main vectors for deepening economic cooperation in the EAEU. Technological modernization of production chains requires the creation of a single digital environment between national business and public authorities [60]. The Eurasian digital platform and its integration with the unified information system of the EAEU will be a mechanism to implement this. Deployment of digital platforms will facilitate efficient use of data throughout the value chain. Thus, the integrated application of digital technologies in sectors opens opportunities for development of new business models. The positive economic effect of the joint digital initiative can increase the total GDP of the participating countries by $11 \%$ by 2025 . This figure is twice higher compared to implementation of digi- tal initiatives separately [61]. In this regard, standardization is the precondition of digitalization projects.

At the supranational level, as well as at the national level, it is necessary to remove legal barriers to the deployment of digital technologies, establish a common digital environment and agree on the basic terminology and concepts related to the digital economy.

\subsection{The Russian approach to standardization of digital manufacturing}

\section{National system of standardization}

Standardization in Russia is now driven mostly by the government, which follows the third model described in this paper. Rosstandart and its technical committees play a key role in the standardization system. Along with Federal Projects implementation, the national standardization system will be modernized by computer models during the lifecycle, sectoral initiatives like smart manufacturing, smart cities, machine-building industry upgrading, information security, etc. Taking into account global trends in alliances and consortia, convergence of digital agendas and approaches to standardization within the EAEU is an important direction for strengthening Russia's position in the area. This requires consolidation of methodological foundations of digital transformation and business involvement [62, 63].

\section{Russian initiatives in the field of digital manufacturing and standardization}

Within the framework of the national program, standards are regarded as a mechanism to stimulate innovative activity of companies. In order to encourage business participation, development procedures of standardization 
documents will be simplified. This will reduce costs to participate in the standardization processes [58]. However, to enlarge business initiatives it also important to create conditions where standards will inevitably succeed both in external and in the internal markets. In other words, the role of standards within the country should be enlarged.

For wide use of digital technologies decision-making based on the experiments with the digital environment, use of digital design and operational documentation, digital product models should be approved. It is anticipated to develop standards in the field of the Internet of Things, cyber-physical systems, big data analysis, etc. [58]. At the beginning of 2019, Rosstandart approved the first national standard of the Internet of Things entitled "A Protocol of wireless data transmission based on narrowband modulation of radio signal (NB-Fi)." This was developed by the Technical Committee 194 "Cyber-physical systems" [64].

In addition to the EAEU level, digitalization issues are being discussed in the Intergovernmental Technical Committee 22 "Information technologies," which operates within the framework of the Interstate Council for Standardization, Metrology and Certification of the CIS [65]. Given the fact that the Committee is a permanent body within the framework of the ISO/IEC 1 joint committee, harmonization of approaches at the level of the CIS is one of the possibilities to promote the Russian approach in digital manufacturing. The Russian standardization system in digital production is presented in Figure 3. Table 2 lists the Russian technical committees (TC) involved in the development of technologies standards.

In 2014-2019, TC focused on new digital technologies were created in artificial intelligence, cyber-physical systems, hardware and software distributed registry and blockchain technologies, robotics, additive manufacturing and digital modeling. An important point is that the technical committee 194 operates on the international level. Along with the harmonization of international standards, the TC develops national standards and promotes them in the ISO and IEC [66]. Russian system standardization also includes national professional consortia and associations, as well as development institutions (JSC RVC, etc.).

\section{Russian technical committees (TC) involved in the development of digital technologies}

Table 2.

\begin{tabular}{|c|c|}
\hline No. of the TC & Name of the TC and year of establishment \\
\hline 164 & Artificial intelligence (2019) \\
\hline 194 & Cyber-physical systems (2017) \\
\hline 159 & Hardware and software distributed registry and blockchain technologies (2017) \\
\hline 141 & Robotics (2016) \\
\hline 182 & Additive manufacturing (2015) \\
\hline 700 & Mathematical modeling and high-performance computing technologies (2014) \\
\hline
\end{tabular}




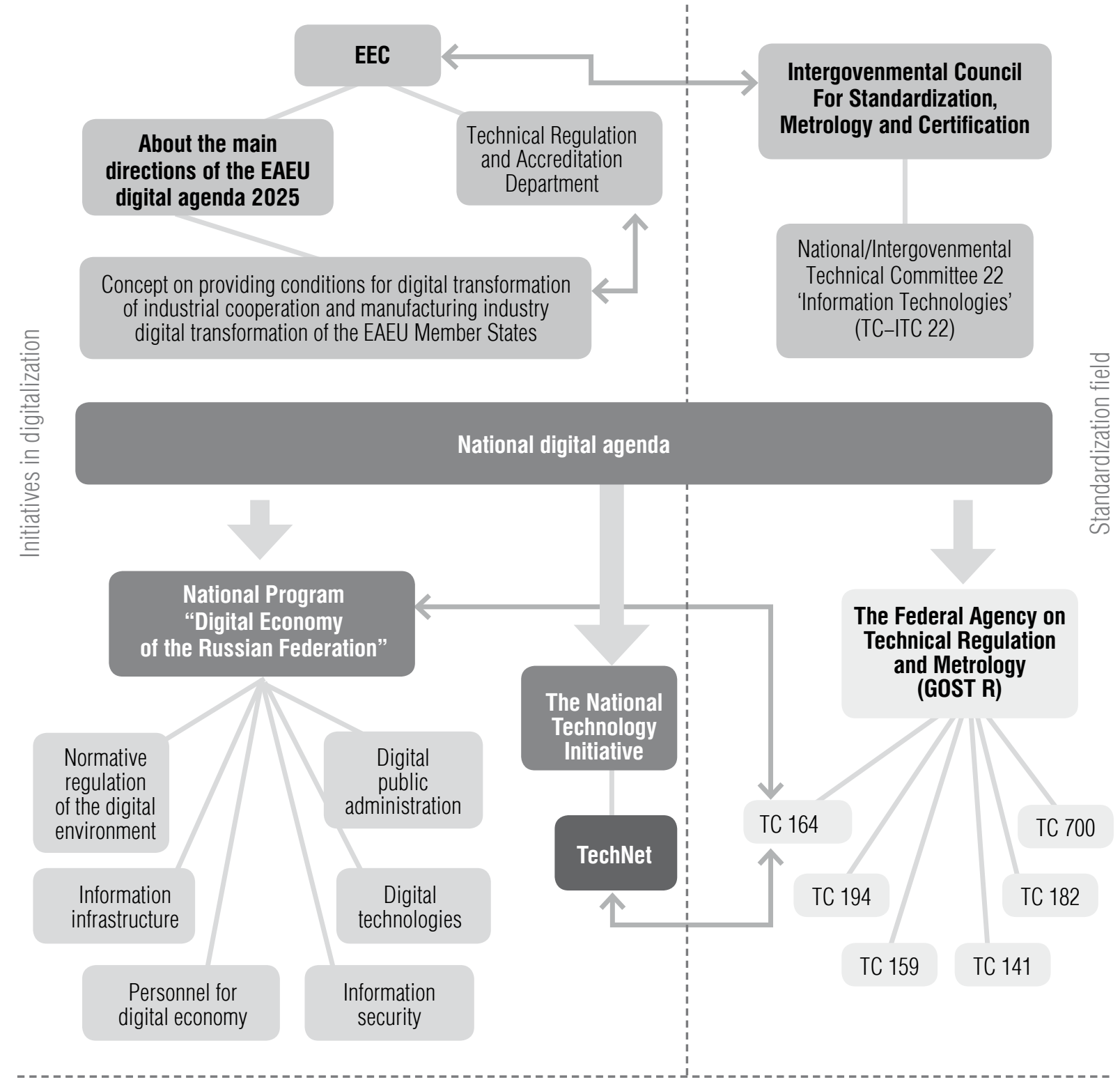

Consortiums and alliances

\begin{tabular}{|c|c|}
\hline Noncommercial & Russian \\
\hline partnership & Association \\
\hline "RUSOFT" & of Robotics \\
\hline (2004) & $(2015)$
\end{tabular}

Russian

Association

of Industrial

Internet (IIC)

(2016)
Internet

of Things

Association

(IOTAS)

(2016)
Development institutions

JSC

"RVC"

Internet

Initiatives

Development

Fund

Fig. 3. The Russian standardization landscape in digital manufacturing 


\section{Russia's cooperation with other countries in the field of digital manufacturing standardization and participation in international organizations}

Currently, Russian business has not established a national approach in digital manufacturing. To this end, it cooperates with German industrial companies and implements their experience in advanced manufacturing technologies. The most obvious examples of cooperation fall within the automotive industry, railway engineering, machine tool industry and some others. By the joint German-Russian GRID initiative, German business shares its experience and uses cases in digital transformation of manufacturing. German business also helps to engage in activities small and medium enterprises that are laggards in digitalization in comparison with large companies [67].

Russia also participates in the ISO and IEC activities focused on digital technologies. National representatives are members of the Smart Manufacturing Coordination Committee (SMCC), the joint ISO and IEC technical Committee and its subcommittees, ISO TC 184. In the IEC Committee TC 65 "Measurement, management and automation of production processes" Russia acts as an observer country.

\section{Implications \\ for Russia in the field \\ of digital manufacturing standardization}

Russian initiatives in transformation of production industries through digital technologies are in line with global trends. It is anticipated to develop standards in such areas as the Internet of Things, cyber-physical systems, etc. At the same time, Russia has not fully established a national model of smart manufacturing digitalization: there is no standardization framework for digital transformation in sectors which will ensure compatibility of systems and consistency with particular sectoral needs.

To date, the level of absorption of digital technologies in industry remains low, since enterprises use a traditional set of information and communication solutions. To a large extent, this is due to the lack of domestic technologies and related standards governing their implementation and use. In order to change the situation, business must be incentivized to create new solutions and further advocate them within the country and outside it. In turn, this requires an appropriate policy that will encourage companies to invest in digital solutions. A broad approach should be implemented, since integration of hardware and software (physical and digital components) becomes essential for complex production systems.

The leading countries in smart manufacturing are trying to ensure market dominance of their standards, references and models. Russia has a number of conditions for sectoral digital transformation, namely dynamically developing ICT: the value added growth of the ICTsector $(2.8 \%)$ in 2017 was almost double the GDP growth (1.6\%) [68]. It also includes the availability of digital products and services that can replace comparable foreign ones, highly qualified personnel in the field of information and communication technologies, as well as talented STEM (Science, Technology, Engineering and Mathematics) graduates. In the framework of the national program "Digital economy of the Russian Federation," a set of new measures of financial support for developing digital technologies is provided. With regard to standards, the program provides an impetus to upgrading the national standardization system and could raise the role of standards in the overall innovation system.

Standardization in digital manufacturing contributes to modernization of the national standardization system and could significantly 
increase the relevance of standards to the innovation system. Use of standards as one of the tools to stimulate digital transformation of industry will require:

$\downarrow$ development of a national model of digital manufacturing standardization;

$\checkmark$ coordination of measures related to standards development within the strategic and program documents;

$\uparrow$ launch and harmonization of sectoral digitalization projects;

development of public-private mechanisms for implementing digital projects;

closer cooperation of working groups of the national project "Digital economy of the Russian Federation," the National Technology Initiative, industrial associations and unions, government agencies and other stakeholders;

$\downarrow$ support for cooperation between technical committees, government agencies, businesses and the scientific community to overcome the fragmentary digitalization in sectors;

- alignment of mechanisms between the national model of digitalization and standardization with that at the EAEU level;

$\downarrow$ exploration of the areas where internationally recognized standards are not currently developed in order to enhance its development.

\section{Conclusion}

The effectiveness of adopting and using digital technologies depends to a large extent on the availability of standards. The main approaches to standardization in digital manufacturing revealed in this paper allowed us to identify mechanisms and directions to digitalization. Standards in the digital era ensure technology transfer and interoperability of systems, including hardware and software elements.

The efforts of the leading countries in the field of smart manufacturing are focused on standards and reference architectures in global market, expansion of bilateral and multilateral cooperation with partner countries concerning standardization issues of digital technologies, as well participating in relevant international organizations.

The Russian digital agenda largely coincides with the international one, however business involvement is still insufficient. With regard to state support, Russia is close to the China model, where standards are a mechanism of structural transformation in industry. In this regard, the development of a common framework for sectoral digitization is a key task of the policy. Its absence creates risks associated with dependence on foreign standards and solutions. Creating a national approach facilitates not only the achievement of the goals set down in the national project "Digital economy of the Russian Federation," but also provides an impetus to the innovation system and technological capabilities of Russian business in the EAEU and CIS. Russia is represented in all key organizations for standardization, but to promote Russian initiatives in digital manufacturing at the international level, especially in the ISO and IEC, it is necessary to provide additional measures and strongly enhance business participation.

Standards have always played a major role in industrial firms. With the rise of digital technologies, standardization patterns in manufacturing draw closer to the ICT. Therefore it could stimulate innovation performance by using diffusion mechanisms attributed to the ICT. This is particularly important for Russia, where low innovation activity hampers digitalization. By implementing new measures of the National Project, standards become an important channel for knowledge diffusion in industry and more broadly for upgrading technology.

The results of the paper can be useful for policymakers responsible for digitalization and digital transformation in industries, as well as for companies and other interested in participating in the national digital agenda stakeholders. 


\section{References}

1. European Commission (2018) Re-Finding Industry Report from the High-Level Strategy Group on Industrial Technologies. Available at: https://ec.europa.eu/research/industrial_technologies/pdf/re_finding_industry_022018. pdf (accessed 10 June 2019).

2. OECD (2017) The Next Production Revolution. Implications for Governments and Business. Available at: https:// espas.secure.europarl.europa.eu/orbis/sites/default/files/generated/document/en/9217031e.pdf (accessed 14 April 2019).

3. Ananyin V.I., Zimin K.V., Lugachev M.I, Gimranov R.D., Skripkin K.G. (2018) Digital organization: Transformation into the new reality. Business Informatics, no 2, pp. 45-54.

4. Park H., Kim H., Joo H., Song J. (2016) Recent advancements in the Internet-of-Things related standards: A oneM2M perspective. ICT Express, vol. 2, no 3, pp. 126-129.

5. Tokareva M.S., Vishnevskiy K.O., Chikhun L.P. (2018) The impact of the Internet of Things technologies on economy. Business Informatics, no 3, pp. 62-78.

6. Ghobakhloo M. (2018) The future of manufacturing industry: a strategic roadmap toward Industry 4.0. Manufacturing Technology Management, vol. 29, no 6, pp. 910-936.

7. Strange R., Zucchella A. (2017) Industry 4.0, global value chains and international business. Multinational Business Review, vol. 25, no 3, pp. 174-184.

8. Akatkin Y.M., Karpov O.E., Konyavskiy V.A., Yasinovskaya E.D. (2017) Digital economy: Conceptual architecture of a digital economic sector ecosystem. Business Informatics, no 4, pp. 17-28.

9. Esmaeilian B., Behdad S., Wang B. (2016) The evolution and future of manufacturing: A review. Journal of Manufacturing Systems, no 39, pp. 79-100.

10. Müller J., Voigt K. (2018) Sustainable industrial value creation in SMEs: A comparison between Industry 4 and Made in China 2025. International Journal of Precision Engineering and Manufacturing-Green Technology, vol. 5, no 5, pp. 659-670.

11. Kagermann H., Anderl R., Gausemeier J., Schuh G., Wahlster W. (2016) Industrie 4.0 in a Global Context: Strategies for Cooperating with International Partners (Acatech STUDY). Munich: Herbert Utz Verlag.

12. Gilchrist A. (2016) Industry 4.0. Apress.

13. Szalavetz A. (2019) Industry 4.0 and capability development in manufacturing subsidiaries. Technological Forecasting and Social Change, vol. 145, pp. 384-395.

14. Weyer S., Schmitt M., Ohmer M., Goreck D. (2015) Towards Industry 4.0 - Standardization as the crucial challenge for highly modular, multi-vendor production systems. IFAC-PapersOnLine, vol. 48, no 3, pp. 579-584.

15. Choi S., Jung C., Kulvatunyou B., Morris K.C. (2016) An analysis of technologies and standards for designing smart manufacturing systems. Journal of Research of the National Institute of Standards and Technology, vol. 121, pp. 422-433.

16. Wakke P., Blind K., De Vries H. (2015) Driving factors for service providers to participate in standardization: Insights from the Netherlands. Industry and Innovation, vol. 4, no 22, pp. 299-320.

17. Blind K., Mangelsdorf A. (2016) Motives to standardize: Empirical evidence from Germany. Technovation, no 48-49, pp. 13-24.

18. Narayanana V.K., Chen T. (2012) Research on technology standards: Accomplishment and challenges. Research Policy, no 41, pp. 1375-1406.

19. Baron J., Ménière Y., Pohlmann T. (2014) Standards, consortia, and innovation. International Journal of Industrial Organization, no 36, pp. 22-35.

20. Zoo H., De Vries H., Lee H. (2017) Interplay of innovation and standardization: Exploring the relevance in developing countries. Technological Forecasting \& Social Change, no 118, pp. 334-348.

21. Wang Z., Zhang M., Sun H., Zhu G. (2016) Effects of standardization and innovation on mass customization: An empirical investigation. Technovation, no 48-49, pp. 79-86.

22. Foster C., Heeks R. (2013) Innovation and scaling of ICT for the bottom-of-the-pyramid. Journal of Information Technology, no 28, pp. 296-315.

23. Kim D.-h., Leeb H., Kwak J. (2017) Standards as a driving force that influences emerging technological trajectories in the converging world of the Internet and things: An investigation of the M2M/IoT patent network. Research Policy, no 46, pp. 1234-1254.

24. Shin D.-H., Kim H., Hwang J. (2015) Standardization revisited: A critical literature review on standards and innovation. Computer Standards \& Interfaces, no 38, pp. 52-57. 
25. Delcamp H., Leiponen A. (2013) Innovating standards through informal consortia: The case of wireless telecommunications. International Journal of Industrial Organization, no 36, pp. 36-47.

26. World Economic Forum (2018) Readiness for the Future of Production Report 2018. Available at: http://www3.weforum.org/docs/FOP_Readiness_Report_2018.pdf (accessed 10 June 2019).

27. United States Government (2018) Strategy for American leadership in advanced manufacturing. Available at: https://www.whitehouse.gov/wp-content/uploads/2018/10/Advanced-Manufacturing-Strategic-Plan-2018.pdf (accessed 10 June 2019).

28. ITIF (2018) Manufacturing digitalization: Extent of adoption and recommendations for increasing penetration in Korea and the U.S. Available at: http://www2.itif.org/2018-korean-manufacturing-digitalization.pdf (accessed 10 June 2019).

29. ITIF (2018) Why manufacturing digitalization matters and how countries are supporting it. Available at: http://www2.itif.org/2018-manufacturing-digitalization.pdf_(accessed 10 June 2019).

30. Ministry of Economy, Trade and Industry (2017) New industrial structure vision. Available at: http://www.meti. go.jp/english/publications/pdf/vision_171222.pdf (accessed 10 June 2019).

31. Second European Standardization Expert in China (2018) Chinese Standards 2035, the standardization strategy research is kicked off. Available at: http://www.sesec.eu/24-05-2018-chinese-standards-2035-thestandardization-strategy-research-is-kicked-off/ (accessed 10 June 2019).

32. Mattauch W. (2017) Digitising European industries - Member states profile: Germany. Available at: https://ec.europa.eu/futurium/en/system/files/ged/de_country_analysis.pdf (accessed 10 June 2019).

33. Federal Ministry for Economic Affairs and Energy (2016) Digital Strategy 2025. Available at: https://www. de.digital/DIGITAL/Redaktion/EN/Publikation/digital-strategy-2025.pdf?_blob=publicationFile\&v=8 (accessed 10 June 2019).

34. Standardization Administration of the P.R.C. (2017) Situation of Chinese intelligent manufacturing standardization \& international cooperation suggestions. Available at: https://www.bmwi-registrierung.de/gpg20sc/ pdf/07.10.\%20Presentation\%20-\%20Ms\%20Hong\%20Dai.pdf (accessed 10 June 2019).

35. DIN (2018) The Reference Architectural Model RAMI 4.0 and the Standardization Council as an element of success for Industry 4.0. Available at: https://www.din.de/blob/271306/340011c12b8592df728bee3815ef6ec2/06-smartmanufacturing-jens-gayko-data.pdf_(accessed 10 June 2019).

36. Kagermann H., Anderl R., Gausemeier J., Schuh G., Wahlster W. (Eds.) (2016) Acatech. Industrie 4. O in a global context. Strategies for cooperating with international partners. Munich: Herbert Utz Verlag.

37. Export.Gov (2018) Korea - Manufacturing Technology - Smart Factory. Available at: https://www.export.gov/ article?id=Korea-Manufacturing-Technology-Smart-Factory (accessed 10 June 2019).

38. Ministry of Science and ICT (2018) Smart Korea Creative Economy. Available at: https://www.msit.go.kr/ SYNAP/skin/doc.html?fn=8a5c9cc0262b0da349d6d641227368a7\&rs=/SYNAP/sn3hcv/result/201908/ (accessed 10 June 2019).

39. IVI (2016) The Industrial Value Chain Initiative. A Japanese contribution to smart manufacturing. Available at: https://iv-i.org/en/docs/doc_160428_hannover.pdf (accessed 10 June 2019).

40. Ministry of Economy, Trade and Industry (2017) “Connected Industries” Tokyo Initiative 2017. Available at: http://www.meti.go.jp/english/press/2017/pdf/1002_004b.pdf (accessed 10 June 2019).

41. Second European Standardization Expert in China (2015) China Internet Plus Strategy. Available at: http://www.sesec.eu/app/uploads/2015/06/2015_05_SESECIII_Newsletter_April_2015_Annex02_China_ Internet_Plus_Strat....pdf (accessed 10 June 2019).

42. DIN (2018) German Standardization Roadmap Industrie 4.0. Version 3. Available at: https://www.din.de/blob/65 354/57218767bd6da1927b181b9f2a0d5b39/roadmap-i4-0-e-data.pdf (accessed 14 January 2019).

43. IVI (2016) Industrial Value Chain Reference Architecture. Available at: https://iv-i.org/en/docs/Industrial Value_Chain_Reference_Architecture_170424.pdf (accessed 10 June 2019).

44. Park S. (2016) Development of innovative strategies for the Korean manufacturing industry by use of the Connected Smart Factory (CSF). Procedia Computer Science, Asan, Korea, 16-18 August 2016, no 91, pp. 744-750. Available at: https://core.ac.uk/download/pdf/82146226.pdf (accessed 10 June 2019).

45. Bundesministerium für Wirtschaft und Energie (2018) Fortschrittsbericht 2018. Industrie 4.0 anwenden. Wegweisend. Praxisnah. Vernetzt. Available at: https://www.plattform-i40.de/I40/Redaktion/DE/Downloads/ Publikation/hm-2018-fortschrittsbericht.pdf?_blob=publicationFile\&v=5 (accessed 10 June 2019).

46. Robot Revolution Initiative (2017) What's RRI / WG1? - toward horizontal dynamic manufacturing. Available at: https://www.jmfrri.gr.jp/content/files/Open/2017/20170315_RRI_forCeBIT/RRI_for_CeBIT_IoT_panel.pdf (accessed 10 June 2019). 
47. Industrial Value Chain Initiative (2018) The Allianz Industrie 4.0 Baden-Württemberg and the Industrial Value Chain Initiative Sign MoU. Available at: https://iv-i.org/wp/wp-content/uploads/2018/03/Allianz-I4.0-IVIMOU-press-release.pdf (accessed 10 June 2019).

48. Fraunhofer IOSB (2019) Smart Factory Web. Available at: https://www.iosb.fraunhofer.de/servlet/is/81769/ (accessed 10 June 2019).

49. Plattform Industrie 4.0 (2018) Paris Declaration for Smart Manufacturing - by the Working Group "Standardization and Reference Architecture" of the Trilateral Cooperation, Digitizing European Industry. Available at: https://www.plattform-i40.de/I40/Redaktion/DE/Downloads/Publikation/wg3-trilaterale-coop.pdf? blob $=$ publicationFile $\& v=6$ (accessed 10 June 2019).

50. Industrial Internet Consortium (2017) The Industrial Internet Consortium and The Industrial Value Chain Initiative Sign MoU. Available at: https://www.iiconsortium.org/press-room/04-26-17.htm (accessed 10 June 2019).

51. Industrial Internet Consortium, Platform Industrie 4.0 (2017) Architecture Alignment and Interoperability and Industrial Internet Consortium and Plattform Industrie 4.0 Joint Whitepaper. Available at: https://www.iiconsortium.org/pdf/JTG2_Whitepaper_final_20171205.pdf (accessed 10 June 2019).

52. HSE (2018) The contribution of digitalization to the growth of the Russian economy. Express-information on digital economy, no. 91 (8). Available at: https://issek.hse.ru/data/2018/07/04/1152915836/NTI_N_91_04072018. pdf (accessed 10 June 2019) (in Russian).

53. McKinsey (2017) Digital Russia: A new reality. Available at: http://www.tadviser.ru/images/c/c2/DigitalRussia-report.pdf_(accessed 10 June 2019) (in Russian).

54. HSE (2018) Digitalization of business processes. Express-information on digital economy, no 98 (9). Available at: https://issek.hse.ru/data/2018/08/22/1154862864/NTI_N_98_22082018.pdf (accessed 10 June 2019) (in Russian).

55. Ministry of Industry and Trade of the Russian Federation (2017) Action plan for import substitution in the machine tool industry of the Russian Federation. Order of the Ministry of Industry and Trade of the Russian Federation, no 4358, 12 December 2017. Available at: https://gisp.gov.ru/plan-import-change/8679776/\#popdoc (accessed 10 June 2019) (in Russian).

56. Ministry of Digital Development, Communications and Mass Media of the Russian Federation (2015) On approval of the import substitution plan]. Order of the Ministry of Digital Development, Communications and Mass Media of the Russian Federation, no 96, 01 April 2015. Available at: http://minsvyaz.ru/uploaded/files/ prikaz-ot-01-04-2015--96.pdf (accessed 10 June 2019) (in Russian).

57. NTI (2018) Action plan ("roadmap") “Technet” (advanced manufacturing technology) of the National technology initiative. Approved by the Presidium of the Council for economic modernization and innovative development of Russia, protocol no 1, 14 February 2017]. Available at: http://www.nti2035.ru/docs/\%D0\%94\%D0\%9A\%20 \%D0\%A2\%D0\%B5\%D1\%85\%D0\%BD\%D0\%B5\%D1\%82\%20-\%20\%D0\%BF\%D1\%80\%D0\%B8\%D0\%B B\%D0\%BE\%D0\%B6\%D0\%B5\%D0\%BD\%D0\%B8\%D0\%B5\%20\%D0\%BA\%20\%D0\%BF\%D1\%80\%D0 $\%$ BE\% $1 \% 82 \% \mathrm{D} 0 \% \mathrm{BE} \% \mathrm{D} 0 \% \mathrm{BA} \% \mathrm{D} 0 \% \mathrm{BE} \% \mathrm{D} 0 \% \mathrm{BB} \% \mathrm{D} 1 \% 83 \% 20 \% \mathrm{D} 0 \% \mathrm{~B} 7 \% \mathrm{D} 0 \% \mathrm{~B} 0 \% \mathrm{D} 1 \% 81 \% \mathrm{D} 0 \% \mathrm{~B}$ 5\%D0\%B4\%D0\%B0\%D0\%BD\%D0\%B8\%D1\%8F\%20\%D0\%BF\%D1\%80\%D0\%B5\%D0\%B7\%D0\%B8\% D0\%B4\%D0\%B8\%D1\%83\%D0\%BC\%D0\%B0\%20\%D0\%A1\%D0\%BE\%D0\%B2\%D0\%B5\%D1\%82\%D0 \%B0.pdf (accessed 10 June 2019) (in Russian).

58. The Government of Russia (2018) The National program "Digital economy of the Russian Federation". Available at: http://static.government.ru/media/files/urKHm0gTPPnzJlaKw3M5cNLo6gczMkPF.pdf (accessed 11.06.2019).

59. Comnews (2019) The Ministry of Industry and Trade outlined the contour of "Digital industry". Available at: https://www.comnews.ru/content/119733/2019-05-23/minpromtorg-ochertil-kontur-cifrovoypromyshlennosti (accessed 10 June 2019) (in Russian).

60. The World Bank (2017) The Digital agenda of the Eurasian economic Union until 2025: Outlook and recommendations. Available at: http://www.eurasiancommission.org/ru/act/dmi/SiteAssets/\%D0\%9E\%D0\%B1 $\% \mathrm{D} 0 \% \mathrm{~B} 7 \% \mathrm{D} 0 \% \mathrm{BE} \% \mathrm{D} 1 \% 80 \% 20 \% \mathrm{D} 0 \% 92 \% \mathrm{D} 0 \% 91 . p d f$ (accessed 10 June 2019) (in Russian).

61. EAEU (2017) About the main directions of implementation of the digital agenda of the Eurasian Economic Union till 2025. Available at: http://www.eurasiancommission.org/ru/act/dmi/workgroup/Documents/\%D0\%9E\% D1\%81\%D0\%BD\%D0\%BE\%D0\%B2\%D0\%BD\%D1\%8B\%D0\%B5\%20\%D0\%B4\%D0\%BE\%D0\%BA $\% \mathrm{D} 1 \% 83 \% \mathrm{D} 0 \% \mathrm{BC} \% \mathrm{D} 0 \% \mathrm{~B} 5 \% \mathrm{D} 0 \% \mathrm{BD} \% \mathrm{D} 1 \% 82 \% \mathrm{D} 1 \% 8 \mathrm{~B} / \% \mathrm{D} 0 \% \mathrm{~A} 0 \% \mathrm{D} 0 \% \mathrm{~B} 5 \% \mathrm{D} 1 \% 88 \% \mathrm{D} 0 \% \mathrm{~B} 5 \% \mathrm{D} 0$ \%BD\%D0\%B8\%D0\%B5\%20\%D0\%92\%D0\%95\%D0\%AD\%D0\%A1\%20\%E2\%84\%9612 \%D0\%9E\%D1\% 81\%D0\%BD\%D0\%BE\%D0\%B2\%D0\%BD\%D1\%8B\%D0\%B5\%20\%D0\%BD\%D0\%B0\%D0\%BF\%D1\%80 $\%$ D0\%B0\%D0\%B2\%D0\%BB\%D0\%B5\%D0\%BD\%D0\%B8\%D1\%8F\%20\%D1\%80\%D0\%B5\%D0\%B0\%D 0\%BB\%D0\%B8\%D0\%B7\%D0\%B0\%D1\%86\%D0\%B8\%D0\%B8\%20\%D1\%86\%D0\%B8\%D1\%84\%D1\%80 $\% \mathrm{D} 0 \% \mathrm{BE} \% \mathrm{D} 0 \% \mathrm{~B} 2 \% \mathrm{D} 0 \% \mathrm{BE} \% \mathrm{D} 0 \% \mathrm{~B} 9 \% 20 \% \mathrm{D} 0 \% \mathrm{BF} \% \mathrm{D} 0 \% \mathrm{BE} \% \mathrm{D} 0 \% \mathrm{~B} 2 \% \mathrm{D} 0 \% \mathrm{~B} 5 \% \mathrm{D} 1 \% 81 \% \mathrm{D} 1 \% 82 \% \mathrm{D}$ 0\%BA\%D0\%B8\%20\%D0\%95\%D0\%90\%D0\%AD\%D0\%A1.pdf (accessed 10 June 2019) (in Russian). 
62. The Government of Russia (2019) On management system of implementation of the national program “Digital economy of the Russian Federation”. Resolution no 234, 2 March 2019. Available at: http://government.ru/docs/35964/ (accessed 10 June 2019) (in Russian).

63. Aviation Union (2018) Draft of "The development concept of the national standardization system up to 2027". Available at: http://www.aviationunion.ru/Files/Cogc_razv_19032018.pdf (accessed 10 June 2019) (in Russian).

64. The Government of Russia (2018) Action plan ("road map") to improve legislation and eliminate administrative barriers in order to ensure the implementation of the National Technology Initiative in the field of "TechNet" (advanced production technologies). Available at: http://www.rvc.ru/upload/doc/NDK_technet.pdf (accessed 10.06.2019) (in Russian).

65. Euro-Asian Council for Standardization, Metrology and Certification (2018) Euro-Asian Council for Standardization. Information about Interstate Technical Committee 22. Available at: http://www.mgs.gost.ru/TKS UGGEST/\%D0\%9C\%D0\%A2\%D0\%9A2014.nsf/84eb0d5919ea20bac325653100289c4a/f26ec86e4be3c56143 25801e00504d7e?OpenDocument (accessed 10 June 2019) (in Russian).

66. Rosstandart (2019) Technical Committee 194. Available at: http://webportalsrv.gost.ru/portal/TKSUGGEST/ TK2006.nsf/84eb0d5919ea20bac325653100289c4a/112ceb451b548663432580f900394dfd?OpenDocument (accessed 10 June 2019) (in Russian_.

67. Germany Trade \& Invest (2018) Deutschland und Russland kooperieren bei Industrie 4.0 Nachholbedarf bei Automatisierung der Produktion bietet Geschäftschancen. Available at: https://www.gtai.de/GTAI/ Navigation/DE/Trade/Maerkte/suche, $\mathrm{t}=$ deutschland-und-russland kooperieren-bei-industrie-40, $\mathrm{did}=1905828 . \mathrm{html}$ (accessed 10 June 2019).

68. HSE (2018) ICT sector in Russia. Express-information on digital economy, no 110 (10). Available at: https:// issek.hse.ru/data/2018/11/14/1141212573/NTI_N_110_14112018.pdf (accessed 10 June 2019) (in Russian).

\section{About the authors}

\section{Yulia V. Turovets}

Expert, Digital Economics Center; Research Assistant,

Research Laboratory for Science and Technology Studies, Institute for Statistical Studies and Economics of Knowledge, National Research University Higher School of Economics, 20, Myasnitskaya Street, Moscow 101000, Russia;

E-mail: yturovecz@hse.ru

ORCID: 0000-0002-6336-1255

\section{Konstantin O. Vishnevskiy}

Cand. Sci. (Econ.), Associate Professor;

Director, Digital Economics Center; Senior Research Fellow, Research Laboratory for Science and Technology Studies, Institute for Statistical Studies and Economics of Knowledge, National Research University Higher School of Economics, 20, Myasnitskaya Street, Moscow 101000, Russia;

E-mail: kvishnevsky@hse.ru

ORCID: 0000-0003-3621-0504 